\title{
Towards microcrystalline silicon n-i-p solar cells with $10 \%$ conversion efficiency
}

\author{
L. Feitknecht, C. Droz, J. Bailat, X. Niquille, J. Guillet, A. Shah \\ Institut de Microtechnique, Université de Neuchâtel, \\ Breguet 2, CH-2000 Neuchâtel, Switzerland.
}

\begin{abstract}
High-performance microcrystalline and amorphous silicon solar cells are the key elements for a successful combination to form the "micromorph" tandem cell [1,2]. A microcrystalline silicon $(\square \mathrm{c}-\mathrm{Si}: \mathrm{H})$ solar cell in the n-i-p configuration was fabricated by the VHF PE-CVD deposition process. The cell has a conversion efficiency exceeding $9 \%\left(\mathrm{~V}_{\mathrm{OC}}=520 \mathrm{mV}\right.$, $\mathrm{FF}=73 \%, \mathrm{~J}_{\mathrm{SC}}=24.2 \mathrm{~mA} / \mathrm{cm}^{2}$ ). This result was achieved by a successful combination of the following elements: first a fine-tuning of the silane concentration (SC) in hydrogen feedstock gas used for deposition of the intrinsic $<\mathrm{i}>$ absorber layer, second, the incorporation of an optimised back-reflecting substrate into the cell; and, third, the ideal combination of each of these keycomponents.

Compared to earlier results with n-i-p-type $\square$ c-Si:H solar cells, a substantial increase in $\mathrm{V}_{\mathrm{OC}}$ was now obtained, while maintaining reasonable $\mathrm{J}_{\mathrm{SC}}$-values. Earlier investigations on the role of the i-layer material had revealed a trade-off between cells with high $\mathrm{J}_{\mathrm{SC}}$ but low $\mathrm{V}_{\mathrm{OC}}$ or cells of low $\mathrm{J}_{\mathrm{SC}}$ and high $\mathrm{V}_{\mathrm{OC}}$. In the present contribution the authors now show the successful combination of a cell with an acceptable $\mathrm{V}_{\mathrm{OC}}$ and good $\mathrm{J}_{\mathrm{SC}}$ generation in the long-wavelength region (above $700 \mathrm{~nm}$ ). This is mainly because of suitable light-diffusing back-reflectors which perform well with respect to both, optical and electrical aspects.
\end{abstract}

\section{INTRODUCTION}

The fabrication of substrate-nip solar cells is substantially different from that of superstrate-pin solar cells, because of the change in the deposition sequence of the layers and its technological consequences (like initial n-type or p-type nucleation layer and optically transparent and doped window-layers). Whereas a relatively large number of papers have dealt with the design and fabrication of superstrate-pin cells, only a relatively small number of papers have looked at substrate-nip cells. The present work is a further contribution to latter topic and will deal with a specific problem in this context:

The interface of the back-TCO (transparent conductive oxide) to the n-type silicon film (we call it here the 'back-interface') takes on a very important role for the deposition of nip-type cells and this interface has an influence on the structure of the whole cell and its performance: Indeed, nucleation of silicon grains, electronic and optical properties are key issues which depend on the nature of the underlying back-TCO material $[3,4]$.

Investigations on the interface of the back-TCO / n-layer of the n-i-p solar cell are not straight-forward since the interesting part is hidden by the solar cell and thus not directly accessible. Since most of the light is absorbed within the first $2 \mu \mathrm{m}$ of the absorber, only the long wavelength part of the light spectrum reaches the back-interface under white-light illumination. A better cell characterisation is possible if the External quantum Efficiency (EQE) measurement is performed from both sides of the cell (double-sided illumination). 


\section{EXPERIMENTAL}

$\mu c-S i: H$ silicon n-i-p solar cells were deposited in a single-chamber VHF-GD reactor at plasma excitation frequencies between 70 to $130 \mathrm{MHz}$. Typical deposition parameters for the intrinsic layer are: base pressure of the vacuum chamber $\mathrm{p}_{\mathrm{base}}<4.1 \mathrm{E}-8 \mathrm{mbar}$, deposition pressure $\mathrm{p}=$ 0.1-0.9 mbar, applied plasma power $\mathrm{P}=5-30 \mathrm{~W}$, substrate temperature around $200{ }^{\circ} \mathrm{C}$. A gas purifier was used to avoid incorporation of detrimental oxygen contamination [5]. These conditions lead to deposition rates in the region of 3 to $10 \AA / \mathrm{sec}$.

Stainless steel and glass substrates were prepared for the back-reflectors which consist of a stack of sputtered silver $(\mathrm{Ag})$ and zinc oxide $(\mathrm{ZnO})$; silver is deposited at substrate temperatures around $400^{\circ} \mathrm{C}$ in order to increase the growth-induced surface-texture (RMS around $60 \mathrm{~nm})$. Current vs. voltage characterisation was performed under AM1.5 conditions at $100 \mathrm{~mW} / \mathrm{cm}^{2}$, using a two-source solar simulator. The short circuit current densities $\left(\mathrm{J}_{\mathrm{SC}}\right)$ were calibrated by the scalar product of the External Quantum Efficiency (EQE) data with the AM1.5 sun spectrum within the range of 350 to $1000 \mathrm{~nm}$. For a better characterisation, we swapped the solar cell in order to illuminate the cell not from the p-side (the normal configuration for thinfilm silicon solar cells) but to illuminate the rear-side of the cell i.e. trough the glass substrate, the back-TCO and the n-layer. Under the n-side illumination, more information on the behaviour of the junction near the back-interface can be obtained.

\section{RESULTS AND DISCUSSION Interfaces}

We deposited in the same deposition-run a nip-type $\square \mathrm{c}-\mathrm{Si}: \mathrm{H}$ cell on substrates which were coated with four different back-TCOs: a) a raw stainless steel plate without any TCO material, b) sputtered $\mathrm{ZnO}$, c) CVD-ZnO and d) CVD-ZnO covered with sputtered $\mathrm{ZnO}$ on top; see Figure 1.

(a)

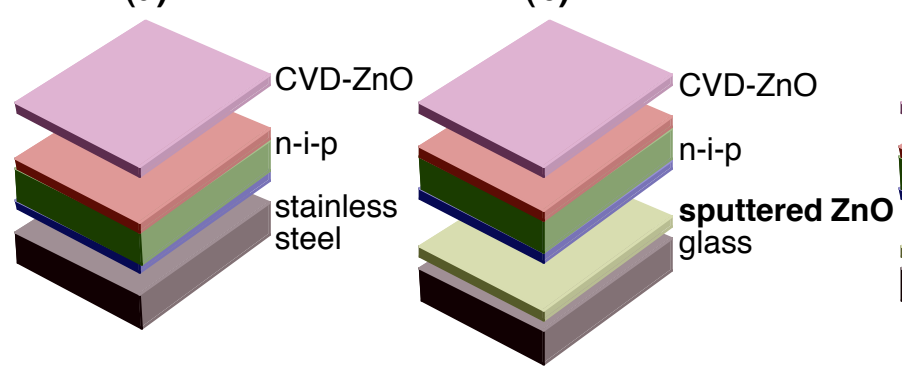

(c)

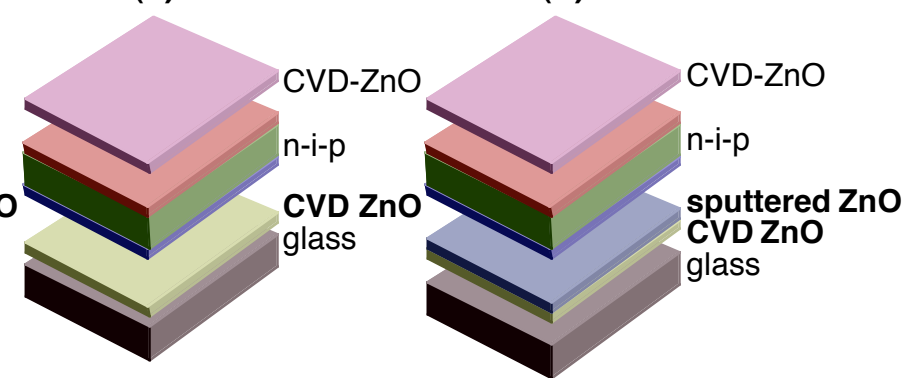

Figure 1: Investigations on the role of the back-interface material: in a single deposition-run, the substrates of (a) stainless steel, (b) glass/sputtered $\mathrm{ZnO}$, (c) glass/CVD-ZnO and (d) glass/CVD$\mathrm{ZnO}$ covered with sputtered $\mathrm{ZnO}$ were processed together.

In Table 1, the electronic cell-characteristics given there highlight the relation of the backinterface to the n-type film of the n-i-p cell. There is a close link between the type of TCO material used and the performance of the solar cell. The best conversion efficiency was achieved on the reference substrate without any $\mathrm{ZnO}$, the next best cell is fabricated on the combined $\mathrm{ZnO}$-back contact (a textured CVD ZnO covered with the non-intentionally textured sputtered $\mathrm{ZnO}$ ). The worst conversion efficiency of this n-i-p cell is reported for the CVD-ZnO backinterface. The EQE curves of these respective cells are given in Figure 2. 
Table 1: Electrical performance of the n-i-p solar cells deposited onto four different back-interface configurations:

\begin{tabular}{|l|l|c|l|c|c|c|c|}
\hline$\#$ & Back-interface & $\begin{array}{c}\mathrm{V}_{\mathrm{OC}} \\
{[\mathrm{mV}]}\end{array}$ & $\begin{array}{l}\mathrm{FF} \\
{[\%]}\end{array}$ & $\begin{array}{l}\mathrm{V}_{\mathrm{OC}} \mathrm{FF} \\
{[\text { a.u. }]}\end{array}$ & $\begin{array}{l}\mathrm{J}_{\mathrm{SC}}: \mathrm{n} / \mathrm{p} \\
{\left[\mathrm{mA} / \mathrm{cm}^{2}\right]}\end{array}$ & $\begin{array}{l}\text { ratio } \\
{[\mathrm{n} / \mathrm{p}]}\end{array}$ & $\begin{array}{l}\square \\
{[\%]}\end{array}$ \\
\hline a) & Stainless steel & 450 & 71.6 & 322 & n.a. $/ 20.9$ & n.a. & 6.7 \\
\hline b) & Sputtered ZnO & 460 & 69.0 & 317 & $10.9 / 17.1$ & 0.64 & 5.4 \\
\hline c) & CVD-ZnO & 438 & 64.2 & 281 & $5.7 / 17.6$ & 0.32 & 4.9 \\
\hline d) & CVD + Sputtered ZnO & 454 & 68.3 & 310 & $11.9 / 18.7$ & 0.64 & 5.8 \\
\hline
\end{tabular}

\section{Double-sided quantum efficiency measurement}

For interpretation, the external quantum efficiency (EQE) data may be subdivided in three intervals, a first range up to $520 \mathrm{~nm}$, the second from $600 \mathrm{~nm}$ to $800 \mathrm{~nm}$ and the third from $800 \mathrm{~nm}$ to $1000 \mathrm{~nm}$. The EQE illuminated from the n-side is zero up to a wavelength of $520 \mathrm{~nm}$ on the back-contact with CVD-ZnO. On the two sputtered samples a considerably higher signal is measured and no difference between the two $\mathrm{ZnO}$ types is apparent, but the values obtained by the n-side EQE curve still remains below the values obtained for the p-side illuminated EQE curve of the cell. In the last interval only, the EQE curve of the cell with CVD-ZnO gains over the EQE curve of the cell with a sputtered $\mathrm{ZnO}$ back-contact: this is an effect of the good light scattering behaviour of the textured, rough CVD-ZnO.

In all curves of p-side illuminated EQE data, there is a slight dip in the region of $600 \mathrm{~nm}$ to $800 \mathrm{~nm}$ : this dip is a sign for the absence of a powerful light-trapping scheme, as one would obtain by e.g. optimised back-reflectors. The dip could also be avoided by increased cell absorber thickness (exceeding $2.5 \mu \mathrm{m}$ ).

\section{TEM investigations}

The Transversal Electron Microscope (TEM) allows for a close look on the nucleation of microcrystalline films on CVD and sputtered $\mathrm{ZnO}$, see Figure. 3. Crystallographic observations help here to highlight one facet of the situation at the $n-i$ interface.
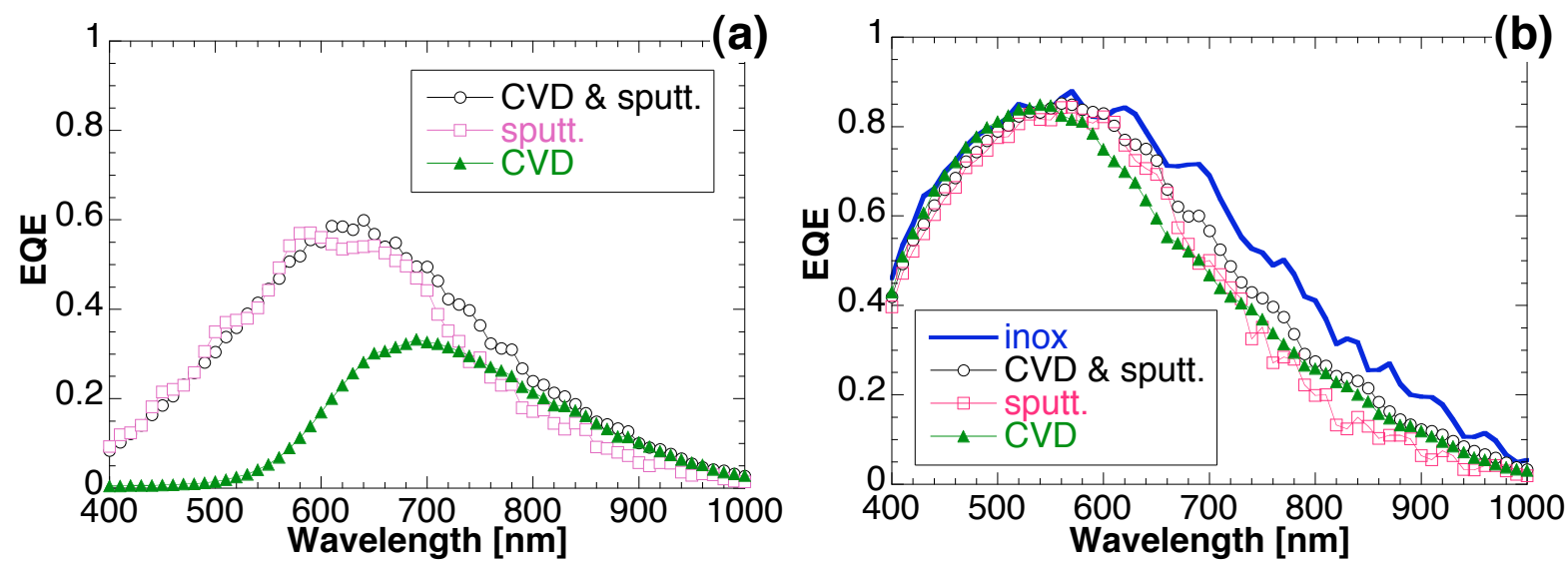

Figure 2: (a) Quantum efficiency measurement illuminated from the n-side and (b) illuminated from the p-side: stainless steel (inox), CVD-ZnO covered with sputtered $\mathrm{ZnO}$, simply sputtered $\mathrm{ZnO}$ and $\mathrm{CVD}-\mathrm{ZnO}$ on glass substrates were utilised respectively. 
(a)

(b)

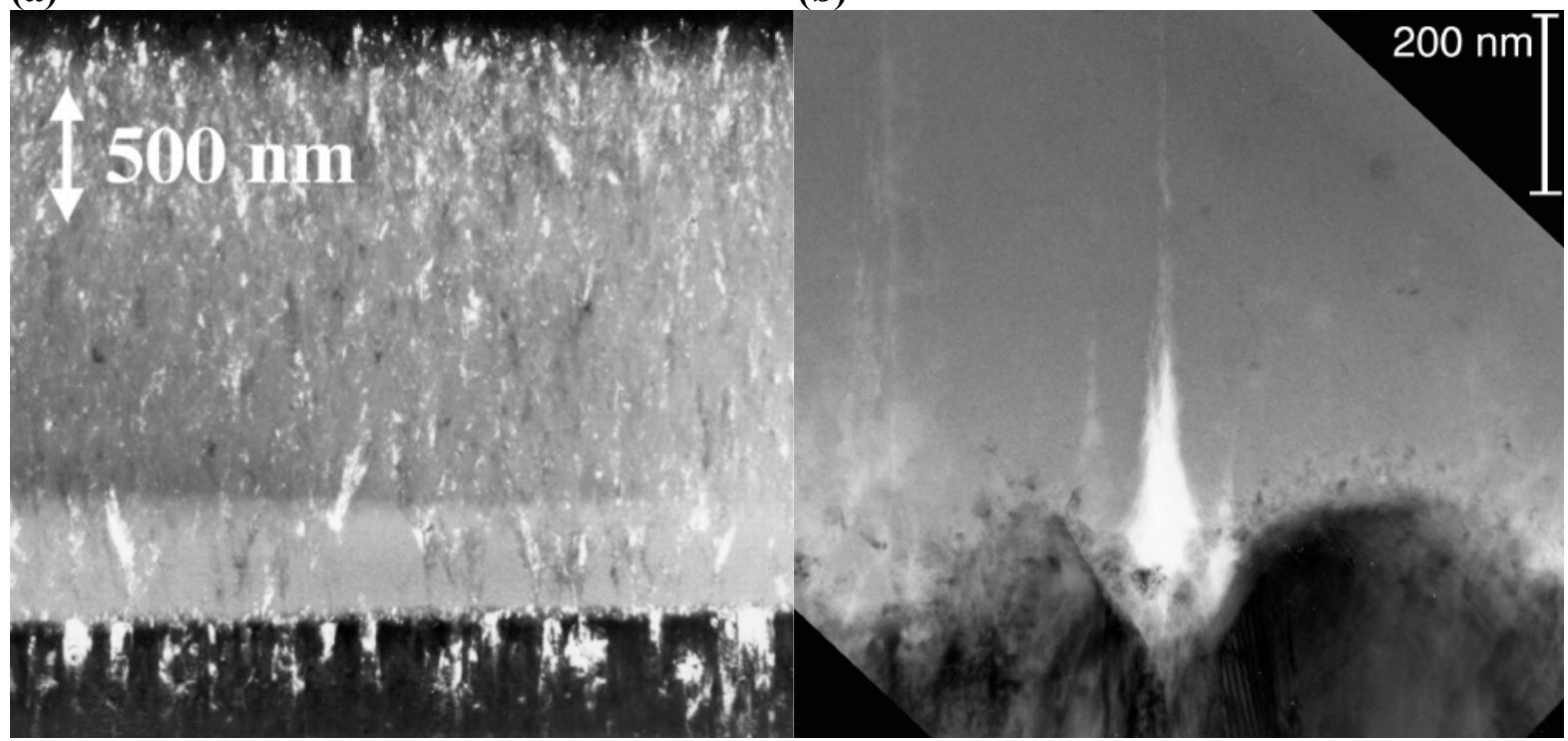

Figure 3: (a) TEM dark field micrograph of a microcrystalline n-i-p solar cell deposited on sputtered $\mathrm{ZnO} . \mathrm{ZnO}$ is at the bottom of the picture, n-type $\square \mathrm{c}-\mathrm{Si}: \mathrm{H}$ layer appears as a thin dotted layer. (b) TEM bright-field micrograph of the $\mathrm{ZnO}$-n-i interface of a solar cell deposited on CVD ZnO. ZnO tetrahedrons are at the bottom of the picture. Note the disordered grainy contrast of the n-layer. A crack/void at the bottom of the $\mathrm{ZnO}$ valley appears bright; source: [4]

Measurements on another series of cells, namely on a "dilution series" of nip-type solar cells (i.e. $n$-i-p solar cells where the intrinsic $<i>$ absorber layers were deposited at various silane concentrations) reveal a systematically denser crystalline structure of the n-layer on sputtered $\mathrm{ZnO}$ than on CVD ZnO. As a consequence of this different n-layer growth, in the initial stage of i-layer deposition, the beginning of the i-layer consists of a mixed-phase layer (amorphous and microcrystalline parts). This layer (also referred to as 'incubation layer') is reported to vary from $140 \mathrm{~nm}$ for cells on sputtered $\mathrm{ZnO}$ to $200 \mathrm{~nm}$ for cells on CVD-ZnO [4,6].

The back-TCO and the electrical characteristics are correlated: The observations of low EQE curves of cells on CVD-ZnO goes in parallel with a poorly formed $n$-film as visible in the TEM images. In the following section, we present possible explanations for this.

\section{Discussion on cell interfaces}

The difficulty to match a certain nip-type solar cell onto different back-contact materials is discussed in the precedent section. A cell might work well in one specific configuration (i.e. for a specific combination of substrate and cell) and the same cell may then show a considerable drop in performance if just the back-contact material is changed. The thin-film solar cell should not be considered as a combination of correctly optimised independent layers, but as a device of both layers and interfaces which have to be optimised on the device itself. Keeping in mind that not only the physical (e.g. crystallographic) but also chemical (out diffusion) and electronic (transport) aspects play important roles in this question, we draw attention to several possible explanations for the observed incompatibility between our present $n-i-p$ cells and certain, specific back-contacts (e.g. CVD-ZnO, here):

$1^{\text {st }}$ If we consider that light of increasing wavelength is absorbed increasingly deeper inside the silicon film, a zone comprising the n-layer and the beginning of the i-layer can be 
made responsible for the non-existent carrier generation/collection in the spectral range of 400 to $520 \mathrm{~nm}$, for the case of cells deposited on CVD-ZnO, as seen in Figure 2(a). This might be due to an optical problem (no photon absorption) or to an electronic problem (no electrical field, and thus no carrier separation). The junction would then lack an electrical field within something like $100 \mathrm{~nm}$ of the $\mathrm{n}-\mathrm{i}$ interface. The most plausible explanation for poor $\mathrm{n}$-film quality in these first $100 \mathrm{~nm}$ would be difference in surface roughness of these two $\mathrm{ZnO}$ types (rough CVD-ZnO and flat sputtered $\mathrm{ZnO}$ ), since deposition onto a flat surface does not lead to the same layer microstructure, as growth on a textured surface [7]: All of the four investigated back-ZnO contacts have different surface roughness. starting from the flat sputtered $\mathrm{ZnO}$ (only $4 \mathrm{~nm}$ of rms roughness) up to the very rough CVD-ZnO (60 $\mathrm{nm}$ of rms roughness). Note that the surface roughness plays a decisive role in the nucleation of the silicon film. A poor nucleation of the silicon layer closest to the back-interface might cause a poor cell performance.

$2^{\text {nd }}$, cross-contamination due to the first stage of the i-layer growth might cause a poor junction within the region of the back-interface (i.e. the region within the n-type and the i-type $\square \mathrm{c}-\mathrm{Si}: \mathrm{H}$ film). On the other hand, a phosphorus contamination due to the preceding deposition of the $n$-film can be excluded: The common problem of contamination in cells fabricated in a single-chamber deposition system would disturb the whole batch of cells. In our case here, cells of the same batch but deposited on CVD-ZnO show a poor EQE signal whereas cells deposited on sputtered $\mathrm{ZnO}$ back-contacts have a higher EQE signal, if we consider wavelengths below $520 \mathrm{~nm}$. Since absorber layer contamination by a preceding $\mathrm{n}$-film would harm the whole batch of cells, independently of the back-contact material, this type of contamination can indeed be excluded.

$3^{\text {rd }}$ The difference of the junction deposited onto the CVD-ZnO and deposited onto the sputtered aluminium doped $\mathrm{ZnO}$ layer might be due to an incompatibility of our n-type film with the CVD-ZnO combining physical (e.g. surface roughness) and chemical reasons.

$4^{\text {th }}$ Another explanation may be the $\mathrm{ZnO}$ surface states which may interact with the deposition plasma of the growing n-type film . Thereby, particles of zinc, oxygen, silicon and phosphorus might get mixed together in the plasma process and create an n-film of a less favourable quality in the case of the CVD-ZnO - something which apparently does not happen on the sputtered $\mathrm{ZnO}$. The term of 'quality' refers here exclusively to crystallographic observations made by TEM, as no doping profile was analysed.

Up to now, not enough measured evidence for or against any of these hypothesis could be given (e.g. SIMS data were not satisfactorily clear). In our eyes, an optimisation of the n-i-p cell interface to the CVD-ZnO back-contact seems generally possible but was sofar beyond the reach of this study.

\section{CONCLUSIONS}

The importance of 'interface-tailoring' for $n-i-p$ solar cells has been made evident in this paper, by giving results on the investigation of four different back-contacts. One must always remember that a thin-film solar cell is not simply a stack of layers but a complex device resulting from an optimal fit of interacting layers. Special care is needed here at the "back-contact interface", i.e. at the interface substrate-silicon. The measurement of quantum efficiency illuminated from both sides contributed considerably to the detection of malfunctions of this "back-contact interface". 

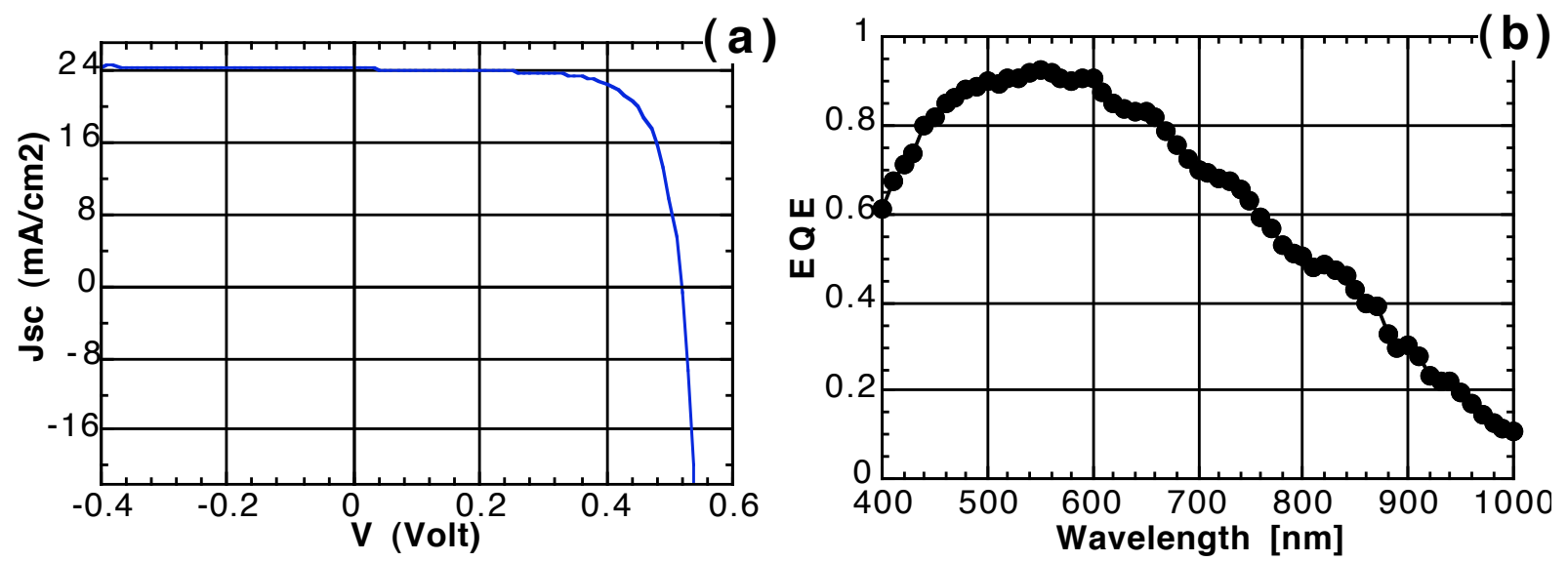

Figure 4: Our sofar best $\square$ c-Si:H solar cell in the n-i-p configuration deposited onto optimised light-scattering back-reflector of glass/silver/sputtered $\mathrm{ZnO}$. AM1.5 conversion efficiency over $9 \%, \mathrm{~V}_{\mathrm{OC}}=520 \mathrm{mV}, \mathrm{FF}=73 \%, \mathrm{~J}_{\mathrm{SC}}=24.2 \mathrm{~mA} / \mathrm{cm}^{2}$, cell surface $=0.3 \mathrm{~cm}^{2}$, thickness $=2.5 \mu \mathrm{m}$.

For industrially relevant solar cell design, the introduction of highly scattering backreflectors is necessary. Theses back-reflectors have to combine two constraints: a good optical performance as well as an optimally designed back-contact to the silicon layer.

The variation of silane concentration of the i-layer of the $n-i-p$ cell is a rather old method (already known for the optimisation of amorphous solar cells [8]) but still applicable to solid $\square \mathrm{c}-\mathrm{Si}: \mathrm{H}$ solar cell fabrication process.

The remarkably good $\square \mathrm{c}-\mathrm{Si}: \mathrm{H}$ n-i-p solar cell (see figure 4) is the result of such an optimisation of the whole device at IMT Neuchâtel. A conversion efficiency exceeding $9 \%$ $\left(\mathrm{V}_{\mathrm{OC}}=520 \mathrm{mV}, \mathrm{FF}=73 \%, \mathrm{~J}_{\mathrm{SC}}=24.2 \mathrm{~mA} / \mathrm{cm}^{2}\right)$ shows exactly the combination of a good $\mathrm{J}_{\mathrm{SC}}$ with a high $\mathrm{V}_{\mathrm{OC}}$. The only drawback of this cell is the low deposition rate of $2.6 \AA / \mathrm{sec}$ which is mainly due to the rather low VHF-plasma frequency of $70 \mathrm{MHz}$. Nevertheless, this is a promising result of a n-i-p solar cell approaching the region of $10 \%$ conversion efficiency.

\section{ACKNOWLEDGEMENTS}

This work was supported by the Swiss Federal Renewable Energy Program (grants 100 045 and 36487 ) and the Swiss National Science Foundation (grant 66985.1).

\section{REFERENCES}

1. L. Feitknecht, O. Kluth, Y. Ziegler, X. Niquille, P. Torres, J. Meier, N. Wyrsch, A. Shah. Sol. En. Mat. \& Solar Cells, Vol. 66, 2001, pp. 397-403.

2. J. Meier, S. Dubail, S. Golay, U. Kroll, S. Faÿ, E. Vallat-Sauvain, L. Feitknecht, J. Dubail, A. Shah, Sol. En. Mat. \& Solar Cells, Vol. 74, 2002, pp. 457-467.

3. H. Fujiwara, M. Kondo, A. Matsuda, J. Appl. Phys., 93 (5): 2400-2409 MAR 12003

4. J. Bailat, E. Vallat-Sauvain, L. Feitknecht, C. Droz, A. Shah, ICAMS 2001, Nice, France, 2001, J. Non-Crystalline Solids Vol. 299-302, pp. 1219-1223.

5. P. Torres et al., Appl. Phys. Lett. 69 (10) 1996 p. 1373

6. J. Bailat, E. Vallat-Sauvain, L. Feitknecht, C. Droz and A. Shah. J. Appl. Phys., Vol. 93, No. 9, 1 May 2003

7. Y. Nasuno, M. Kondo and A. Matsuda, Jpn. J. Appl. Phys. Vol. 40 (2001) L303-L305, Part 2, No. 4A, 1 April 2001

8. R. Platz, S. Wagner, C. Hof, A. Shah et al., J. Appl. Phys. 84 (7): 3949-3953 OCT 11998 